ISSN No. 0974-035X

An Indexed, Refereed \& Peer Reviewed Journal of Higher Education

Towards Excellence

UGC-HUMAN RESOURCE DEVELOPMENT CENTRE,

GUJARAT UNIVERSITY, AHMEDABAD, INDIA

\title{
"COMPARATIVE STUDY OF NONPERFORMING ASSETS WITH" SPECIAL REFERENCE TO PUBLIC SECTOR BANKS
}

\section{Ms. Dipa S. Tank}

\&

\section{Dr. Jignesh Kauangal}

\begin{abstract}
Indian banking sector plays an important role in economic development of the country. Banking sector provide funds for productive purposes, intermediating flow of funds from surplus to deficit units and supporting financial and economic policies of government. Public Sector Banks are the major player to develop the economy. But Gross NPA and Net NPA are the main concerns for banking sector in India because it's reflect the performance of banks. High Gross NPA and Net NPA reflect quality of loan and efficiency of the bank, which increases credit defaults and that, affects the profitability of banks. Public Sector banks face the serious problem of Gross NPA and Net NPA. To improve the efficiency and profitability of banks, the NPA need to be reduced and controlled." This study is based on different trends of nonperforming assets of Public Sector banks. This research paper works on "Comparative Study of Nonperforming Assets with Special reference to Public Sector Banks
\end{abstract}

\section{Key words: Public Sector Banks, Gross Nonperforming Assets, Net Nonperforming} Assets

\section{Introduction}

The Concept of Nonperforming Assets was first time introduced by Narasimham Committee during $17^{\text {th }}$ December, 1991. Nonperforming Asset (NPA) is a loan or advance for which the principal or interest payment remained overdue for a period of 90 days. The loan is shifted to 
Towards Excellence: An Indexed, Refereed \& Peer Reviewed Journal of Higher Education / Ms. Dipa Tank \& Dr. Jignesh Kauangal / Page 33-47

Non-performing asset, when bank will give credit facility to borrower, but borrower made default on payment of principal amount with rate of interest, which adversely affects income off the bank. NPA reduces the profit of the banks. NPA are problematic for financial institutions, since they depend on interest payments for income.

In accordance with asset classification norms brought in with effect from March 31, 2004, a non-performing asset (NPA) is a loan or an advance, where

- Interest and /or installment of principal remain overdue for a period of more than 90 Days in respect of a Term Loan,

- The account remains 'out of order' for a period of more than 90 days, in respect of an Overdraft/ cash credit (OD/CC)

- The bill remains overdue for a period of more than 90 days in the case of bills Purchased and discounted,

- Interest and/ or installment of principal remains overdue for two harvest seasons but for a period not exceeding two half years in the case of an advance granted for agricultural purpose, and

- Any amount to be received remains overdue for a period of more than 90 days in respect of other accounts.

- No active transactions in the account (Cash Credit/Over Draft/EPC/PCFC) for more than 91days

\section{Classification of Asset}

Assets are classified into four categories:

(1) Standard Assets

(2) Sub standard Assets

(3) Doubtful Assets

(4) Loss Assets

\section{(1)Standard Assets}

A standard asset is not a NPA, it's a performing asset. Under standard assets, bank gets interest as well as the principal amount of the loan regularly from the customer. So, these are 
Towards Excellence: An Indexed, Refereed \& Peer Reviewed Journal of Higher Education / Ms. Dipa Tank \& Dr. Jignesh Kauangal / Page 33-47

regular and performing asset, and there are no adverse features. They do not disclose any credit problem.

\section{(2)Sub standard Assets;-}

Sub standard assets are those assets, which are considered as non-performing for a period of 12 months

\section{(3) Doubtful Assets:}

Doubtful assets are those assets, which are considered as non-performing for period of more than 12 months.

\section{(4) Loss assets:}

Loss assets are those where loss has been identified by the bank or internal /external auditors or RBI inspectors but the amount has not been written off, wholly or partially.

\section{Types of NPA}

There are two types of Nonperforming Assets.

1) Gross Nonperforming Assets.

2) Net Nonperforming Assets.

\section{Gross NPA:}

Gross NPA refers to all NPA on a bank's balance sheet irrespective of the provisions made. It consists of all the non standard assets like as sub-standard, doubtful, and loss assets. NPA reflects the quality of the loans made by banks.

\section{Net NPA:}


Net NPA is gross NPA less provisions. Net NPA shows the actual burden of banks. Since in India, bank balance sheets contain a huge amount of NPAs and the process of recovery and write off of loans is very time consuming, the provisions the banks have to make against the NPAs according to the central bank guidelines, are quite significant. That is why the difference between gross and net NPA is quite high.

\section{Reasons for increasing NPA}

According to the recent study conducted by RBI, The factors responsible for increasing NPA are as under.

(1) Internal factors

(2) External factors

(3) Other factors

\section{Internal factors}

- Diversion of fund for expansion, diversification, modernization or for taking up new projects.

- Diversion of fund for assisting or promoting associate concerns.

- Time or cost overrun during the project implementation stage.

- Business failure due to product failure, failure in marketing etc.

- In efficiency in bank management.

- Slackness in credit management and monitoring.

- In appropriate technology or problems related to modern technology.

\section{External factors}

- Recession in the economy as a whole.

- Input or power shortage.

- Price escalation of inputs.

- Exchange rate fluctuations

- Change in government policies

\section{Other factors}


Towards Excellence: An Indexed, Refereed \& Peer Reviewed Journal of Higher Education / Ms. Dipa Tank \& Dr. Jignesh Kauangal / Page 33-47

- Liberalization of the economy and the consequent pressures from liberalization like several competitions, reduction of tariffs etc.

- Poor monitoring of credits and failure to recognize early warning signals shown by standard assets.

- Sudden crashing of capital market and inability to raise adequate funds.

- Mismatching of funds i.e. using loan granted for short term for long term transactions.

- Granting of loans to certain sectors of the economy on the basis of government directives rather than commercial imperatives

\section{Review of Literature}

Dr. Vijay Singh Hooda (2014) studied "Progress of District Central Co-operative Banks in India: A Snapshot on Productivity". Researcher has concluded that employees of DCCBs have been working efficiently for improving the productivity of their respective banks. Branchwise productivity of the banks has been increased with good growth rate. But, employee-wise productivity has been increased with higher rate than that of branch wise productivity. Employees of DCCBs have worked efficiently and effectively. DCCBs faces some problems like dual control, lack of professionalism, low level of technology and less focus on holding training and development programmes for their employees. The need of the time is that government should see the co-operative banking model as a suitable structure for achieving the goals of financial inclusion. This system would be economical and provide results quickly if it is monitored properly and the role of DCCBs will be very impressive for the same.

Laveena and Hitesh kumar(2016) conducted a study the topic of " Management Of NonPerforming Assets On Profitability Of Public And Private Sectors Banks" Researchers conclude that NPA affects the bank profitability and It create more problems in public banks compare to private banks. And banks take serious steps like preventive management and curative management for recovery of Nonperforming assets and there is need to make modification in recovery management. According to them, the flow of NPA in public sector banks is more than as compared to private sector banks, and there is need to take serious 
Towards Excellence: An Indexed, Refereed \& Peer Reviewed Journal of Higher Education / Ms. Dipa Tank \& Dr. Jignesh Kauangal / Page 33-47

action to recover NPA and low NPA ratio and perform well because it affects bank profitability and goodwill and cycling of banking system.

\section{Ms. Asha Singh(2013), studied "Performance of Nonperforming Assets (NPAS) In}

Indian Commercial Banks" Ms. Asha Singh, in her research paper titled "Performance of Nonperforming Assets in Indian Commercial Banks" evaluated that NPA reflect the overall performance of the banks. The Indian banking sector faced a serious problem of NPA. A high level of NPA suggests high probability of a large number of credit defaults that affect the profitability and liquidity of banks. The extent of NPA has comparatively higher in public sectors banks. To improve the efficiency and profitability, the NPA have to be scheduled. Various steps have been taken by government to reduce the NPA. It is highly impossible to have zero percentage NPA. But at least Indian banks should take care to ensure that they give loans to creditworthy customers.

Narula and Singla (2014) studied the "Nonperforming assets of Punjab National Bank and its impact on profitability \& to see the relation between total advances, Net Profits, Gross \& Net NPA". Researcher concludes that there is a positive relation between Net Profits and NPA of PNB. It is because of the mismanagement on the side of bank.

Suresh Babu K N and Dr. Suresh Ramana Mayya (2016), studied "Management of NPA in Selected Cooperative Banks with special Reference to D. K. District, Karnataka, India”, Researcher evaluated that NPA is one of the biggest problems have been facing by the cooperative societies. There is a direct link in between nonperforming assets profitability of the bank. The bank can able to reduce the non performing assets; ultimately the bank can able to improve the profitability. The study discloses that GPACS (Guruvayanakere Primary Agricultural Co-operative Society Limited) bank have more control over NPA than MPACS ( Madanthyar Primary Agricultural Co-operative Society limited) bank.

Vivek Rajbahadur Singh (2016), conducted a study, "A Study of Non-Performing Assets of Commercial Banks and it's recovery in India”. Researcher concludes that, the money locked up in NPA has a direct impact on profitability of the bank as Indian banks are highly dependent on income from interest on funds lent. His study shows that extent of NPA is comparatively very high in public sectors banks. Although various steps have been taken by 
government to reduce the NPAs but still a lot needs to be done to curb this problem. The NPAs level of our banks is still high as compared to the foreign banks. It is not at all possible to have zero NPAs. The bank management should speed up the recovery process. The problem of recovery is not with small borrowers but with large borrowers and a strict policy should be followed for solving this problem. The government should also make more provisions for faster settlement of pending cases and also it should reduce the mandatory lending to priority sector as this is the major problem creating area. So the problem of NPA needs lots of serious efforts otherwise NPAs will keep killing the profitability of banks which is not good for the growing Indian economy at all.

\section{Selection of Banks}

Researcher has selected 4 Public Sector Banks for the study.

- State Bank of India

- Bank of India

- Bank of Baroda

- Central Bank of India.

\section{Scope of the Study}

The study covers the following scope:

- The study of Nonperforming assets is very important in public sector banks because increasing trend of nonperforming will affect the financial health of the public sector banks

- The study can suggest measures for the banks to keep away from future NPAs and to reduce existing NPA.

- The study will help the government, to create and implement new strategies to control NPA of public sector Banks.

\section{Objective of the Study}

The objectives of the present study are: 
- To study the position of Non Performing Assets (NPAs) and Net Nonperforming Assets of public sector banks, like SBI, BOI, BOB and CBI.

- To identify the reasons for increasing NPAs of public sector Banks in India.

- To make suggestions for improvement of recovery of public Sector Banks.

\section{Hypotheses}

Ho: There is no significance difference in Growth of Gross Nonperforming Assets of selected Public Sector Banks.

Ho: There is no significance difference in Growth of Net Nonperforming Assets of selected Public Sector Banks

\section{Research Methodology}

The study is planned to be carried out with the help of secondary data for the purpose to and understand the NPA level of public sector Banks.

\section{Secondary Data}

The present study is mainly based on secondary data. The required data were collected from the annual reports of the Banks, RBI reports, documents, different literature books, journals, news papers, magazines, and various websites of respected banks and etc.

\section{Statistical Analysis}

Data presents in the form of Graphs and Tables. Then it is analyzed and interpreted through statistical techniques i.e. Average and statistical test like T or F.

\section{Analysis and Hypothesis testing of Gross Nonperforming Assets of public Sector Banks}

\begin{tabular}{|c|c|c|c|c|}
\hline $\begin{array}{c}\text { Name } \\
\text { Of } \\
\text { Bank }\end{array}$ & SBI & BOI & BOB & CBI \\
Year & & & & \\
\hline
\end{tabular}


Towards Excellence: An Indexed, Refereed \& Peer Reviewed Journal of Higher Education / Ms. Dipa Tank \& Dr. Jignesh Kauangal / Page 33-47

\begin{tabular}{|c|c|c|c|c|}
\hline $2007-08$ & 12837 & 1932 & 1981 & 2350 \\
\hline $2008-09$ & 15589 & 2471 & 1843 & 2316 \\
\hline $2009-10$ & 19535 & 4882 & 2401 & 2458 \\
\hline $2010-11$ & 25326 & 4812 & 3153 & 2394 \\
\hline $1011-12$ & 39676 & 5894 & 4465 & 7273 \\
\hline $2012-13$ & 51189 & 8765 & 7983 & 8456 \\
\hline $2013-14$ & 61605 & 11869 & 11876 & 11500 \\
\hline $2014-15$ & 56725 & 22193 & 16261 & 11873 \\
\hline $2015-16$ & 98173 & 49879 & 40521 & 22721 \\
\hline $2016-17$ & 112343 & 52045 & 42719 & 27251 \\
\hline Total & 492998 & 164742 & 133203 & 98592 \\
\hline Mean & 49299.8 & 16474.2 & 13320.3 & 9859.2 \\
\hline
\end{tabular}

\section{Source - Annual Reports of Banks}

\section{Growth of Gross Nonperforming Assets}

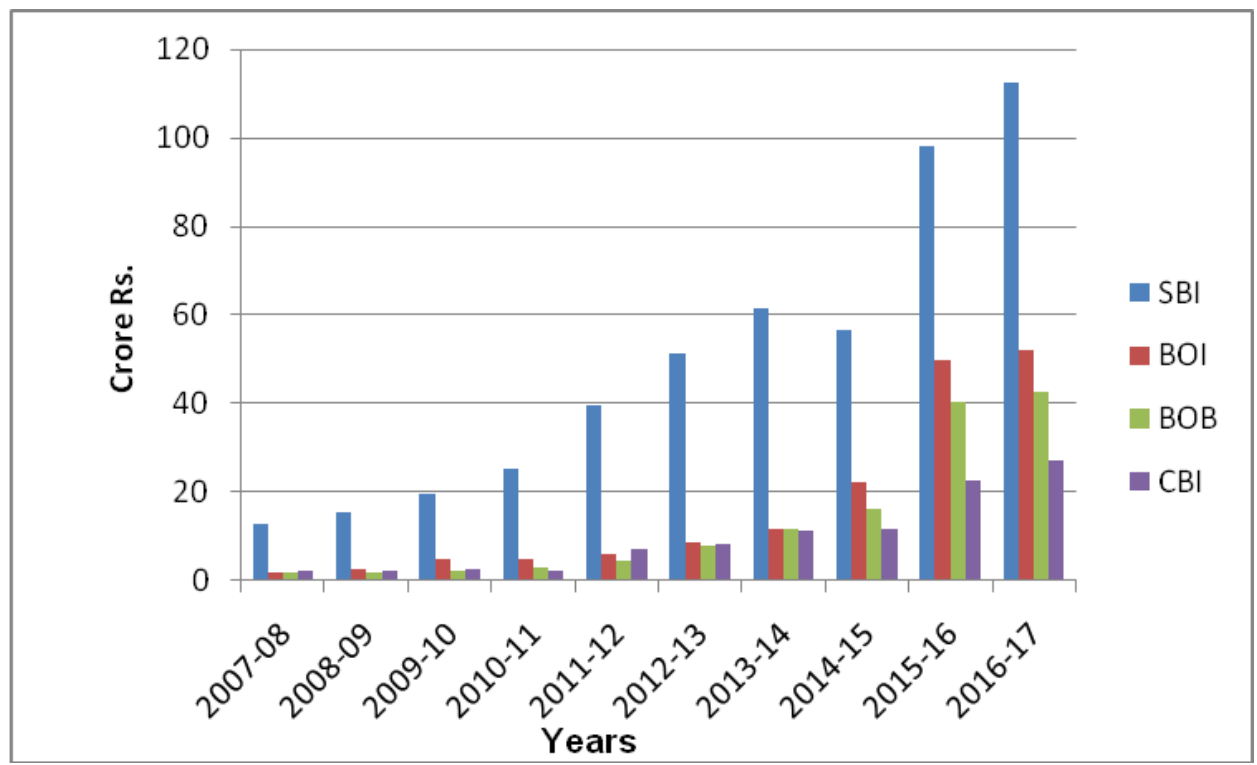

Above table and figure indicates the movement of Gross Nonperforming Assets of Public sector Banks during 2007-08to 2016-17. Gross Nonperforming Assets of SBI has increased from 12837 crores to 112343 crores during 2007-08 to 2016-17, except 2014-15. Similarly, BOI and CBI have shown increasing trend during 2007-08 to 2016-17, except 2010-11.BOB has shown positive trend except 2008-09. The average of Net Nonperforming Assets of SBI is 49299.8 crores, BOI is 16474.2 crores, BOB is 13320.3 crores and CBI is 9859.2 crores during the period of study. 
Towards Excellence: An Indexed, Refereed \& Peer Reviewed Journal of Higher Education / Ms. Dipa Tank \& Dr. Jignesh Kauangal / Page 33-47

Ho: There is no significance difference in Growth of Gross Nonperforming Assets of selected Public Sector Banks

ANOVA TABLE

\begin{tabular}{|c|c|c|l|l|}
\hline Sources & SS & df & MS & \\
\hline $\begin{array}{c}\text { Between } \\
\text { Treatments }\end{array}$ & 9983224718.475 & 3 & 3327741572.825 & F=7.13571 \\
\hline $\begin{array}{c}\text { Within } \\
\text { Treatments }\end{array}$ & 16788623986.9 & 36 & 466350666.3028 & \\
\hline Total & 26771848705.375 & 39 & & \\
\hline
\end{tabular}

From the above table, at 5\% level of significance and 3, 36 d.f., the calculated value of $\mathrm{F}$ is 7.13571 and the Tabulated value of $\mathrm{F}$ is 2.8

Therefore calculated value of $\mathrm{F}>$ Tabulated value of $\mathrm{F}$

More over the value

$\mathrm{p}=0.0007<0.05$. So Null Hypothesis is rejected and alternative hypothesis is accepted.

Therefore it can be said that there is significance difference in growth of Gross Nonperforming Assets of selected Public Sector Banks.

\section{Analysis and Hypothesis testing of Growth of Net Nonperforming Assets of public Sector banks}

Public Sector Banks

Rs. In Crores

\begin{tabular}{|c|c|c|c|c|}
\hline $\begin{array}{c}\text { Name } \\
\text { Of } \\
\text { Bank }\end{array}$ & SBI & BOI & BOB & CBI \\
\hline Year & & & & \\
\hline $2007-08$ & 7424 & 592 & 494 & 1060 \\
\hline $2008-09$ & 9552 & 628 & 451 & 1063 \\
\hline $2009-10$ & 10870 & 2207 & 602 & 727 \\
\hline $2010-11$ & 12347 & 1945 & 791 & 847 \\
\hline $2011-12$ & 15819 & 3656 & 1544 & 4557 \\
\hline $2012-13$ & 28782 & 5947 & 4192 & 4988 \\
\hline $2013-14$ & 42204 & 7417 & 6035 & 6649 \\
\hline
\end{tabular}

DEC, 2017. VOL.9. ISSUE NO. 3 
Towards Excellence: An Indexed, Refereed \& Peer Reviewed Journal of Higher Education / Ms. Dipa Tank \& Dr. Jignesh Kauangal / Page 33-47

\begin{tabular}{|c|c|c|c|c|}
\hline $2014-15$ & 37813 & 13518 & 8070 & 6807 \\
\hline $2015-16$ & 55807 & 27996 & 19407 & 13242 \\
\hline $2016-17$ & 58277 & 25305 & 18080 & 14218 \\
\hline Total & 278895 & 89211 & 59666 & 54158 \\
\hline Mean & 27889.5 & 8921.1 & 5966.6 & 5415.8 \\
\hline
\end{tabular}

Source: - Annual Reports of Banks

\section{Growth of Net Nonperforming Assets}

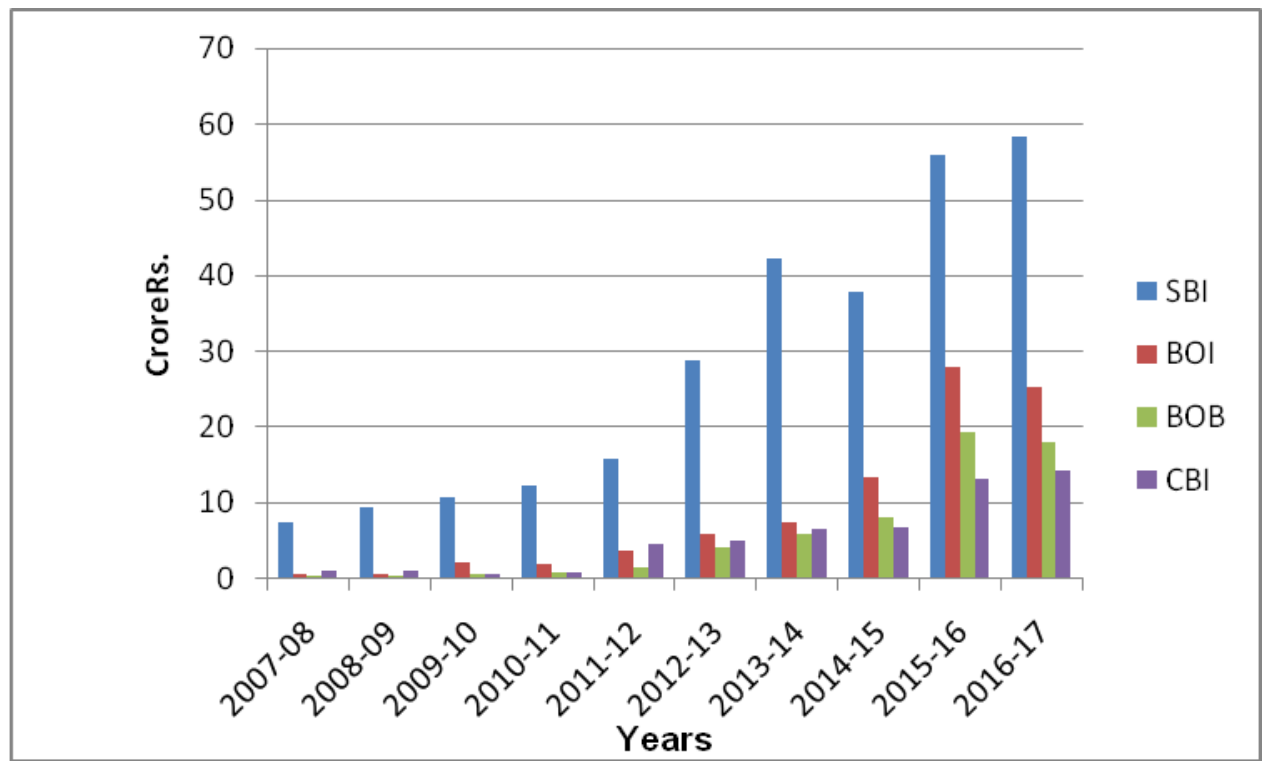

Above table and figure indicates the movement of Net Nonperforming Assets of Public Sector Bank during 2007-08 to 2016-17. SBI has shown positive trend except 2014-15. BOI and CBI were revealed fluctuations in the trend from 592 crores to 25305 crores and 1060 to 14218 respectively. BOB has shown positive trend from 494 crores to 18080 crores, except 2008-09 and 2016-17. The average of Net Nonperforming Assets of SBI is 27889.5 crores, BOI is 8921.1 crores, BOB is 5966.6 crores and CBI is 5415.8 crores during the period of study. The average of Gross Nonperforming Assets of SBI is the uppermost as compared to other Public Sector Banks. The average of Net Nonperforming Assets of SBI is 27889.5 crores, BOI is 8921.1 crores, BOB is 5966.6 crores and CBI is 5415.8 crores during the period of study. The average of Gross Nonperforming Assets of SBI is the uppermost as compared to other Public Sector Banks. 
Towards Excellence: An Indexed, Refereed \& Peer Reviewed Journal of Higher Education / Ms. Dipa Tank \& Dr. Jignesh Kauangal / Page 33-47

Ho: There is no significance difference in Growth of Net Nonperforming Assets of selected Public Sector Banks

ANOVA TABLE

\begin{tabular}{|c|l|c|l|l|}
\hline Sources & \multicolumn{1}{|c|}{ SS } & df & MS & \\
\hline $\begin{array}{c}\text { Between } \\
\text { Treatments }\end{array}$ & 3417001284.1 & 3 & 1139000428.0333 & \\
\hline $\begin{array}{c}\text { Within } \\
\text { Treatments }\end{array}$ & 5057470285.4 & 36 & 140485285.7056 & $\mathrm{~F}=8.10761$ \\
\hline Total & 8474471569.5 & 39 & & \\
\hline
\end{tabular}

From the above table, at 5\% level of significance and 3, 36 d.f., the calculated value of $\mathrm{F}$ is 8.10761 and the Tabulated value of $\mathrm{F}$ is 2.8

Therefore calculated value of $\mathrm{F}>$ Tabulated value of $\mathrm{F}$

More over the value

$\mathrm{p}=0.000297<0.05$. So Null Hypothesis is rejected and alternative hypothesis is accepted. Therefore it can be said that there is significance difference in Growth of Net Nonperforming Assets of selected Public Sector Banks.

\section{Conclusion}

NPA is one of the major problems, which have been faced by the Public sector Banks. Gross Nonperforming Assets and Net Nonperforming Assets of SBI, BOI, BOB and CBI were rising during the period of study. Gross Nonperforming Assets and Net Nonperforming Assets of SBI are upmost as compared to other three public sector Banks. The bank can able to reduce the non performing assets through such steps, which increases the profitability of public sector Banks.

\section{Limitation of the Study}

- The study of non-performing assets limited to the selected 4 public sector banks.

- In this research only selected Co-operative and public and sector banks are covered. Private Banks and foreign banks working in India could not cover. So, it is very difficult to reach proper conclusion regarding NPA of banking sector. 
Towards Excellence: An Indexed, Refereed \& Peer Reviewed Journal of Higher Education / Ms. Dipa Tank \& Dr. Jignesh Kauangal / Page 33-47

- The study period is fixed for ten years only since 2007-08 to 2016-17.

- NPAs are changing with the time. The study is done in the present environment without foreseeing future developments.

\section{Suggestions}

- Public Sector Banks should check the regular default and rectified it on right time.

- The Public Sector Banks should regularly check recovery of periodical installments and close monitoring timely review and renewals of credit limits

- The Public Sector Banks should start such recovery camps in centers like panchayat board offices, court buildings, government department buildings etc. Borrowers were convenient to attend these types of recovery camps and they try to repay their installments of loan.

- Manager of Public Sector Banks should visit each house of the borrowers, and recover the installments due, in respect of loans availed by them.

- The Public Sector Banks should provide training and awareness programs, about the repayment of loans, effective use of funds, repercussions of default etc., for effective utilization of existing funds and for smooth recovery.

- The Public Sector banks should take the necessary action against the defaulters like publishing their names in the local news papers, broadcasting media, which is helpful to other Public Sector banks and financial institutions.

- Public Sector Banks should improve the loan recovery methods and structure of loan.

- Manager of the Public Sector Banks should frequently discuss with their staff and taking their suggestions for recovery of dues. 
Towards Excellence: An Indexed, Refereed \& Peer Reviewed Journal of Higher Education / Ms. Dipa Tank \& Dr. Jignesh Kauangal / Page 33-47

- RBI should modify existing credit appraisals and monitoring systems.

\section{References}

Ashly Lynn Joseph and Dr. M. Prakash, (2014) "A Study on Analyzing the Trend of NPA Level in Private Sectors Banks and Public Sector Banks", International Journal of Scientific and Research Publications, Volume 4, Issue 7, July 20141 ISSN 2250-3153

Dr. Vijay Singh Hooda," Progress of District Central Co-operative Banks in India: A Snapshot on Productivity”, Pacific Business Review International Volume 7, Issue 2, August 2014

Laveena and Hitesh kumar(2016) studies the topic of "Management Of Non-Performing Assets On Profitability Of Public And Private Sectors Banks" International Journal of Research in Management \& Technology (IJRMT), ISSN: 2249-9563 Vol. 6, No.2, Mar-Apr. 2016

Ms. Asha Singh(2013), studied "Performance of Nonperforming Assets (NPAS) In Indian Commercial Banks" International Journal of Marketing, Financial Services \& Management Research, ISSN 2277- 3622 Vol.2, No. 9, September (2013)

Suresh Babu K N and Dr. Suresh Ramana Mayya (2016), Management of NPA in Selected Cooperative Banks with special Reference to D. K. District, Karnataka, India, International Journal of Commerce, Business and Management (IJCBM), ISSN: 2319-2828, Vol. 5, No.1, Jan- Feb. 2016

Vivek Rajbahadur Slingh (2016), “A Study of Non-Performing Assets of Commercial Banks and it's recovery in India” Annual Research Journal of SCMS, Punae Vol. 4, March 2016

Narula, S., \& Singla, M. (2014). Empirical Study on Non Performing Assets of Bank. Internationa Journal of Advance Research in Computer Science and Management Studies, Vol. 2, 2014 
Towards Excellence: An Indexed, Refereed \& Peer Reviewed Journal of Higher Education / Ms. Dipa Tank \& Dr. Jignesh Kauangal / Page 33-47

Websites

1. www.bankofindia.co.in

2. www.bankofbaroda.co.in

3. www.centralbankofindia.co.in

4. www.sbi.co.in

Dipa S. Tank

Research scholar

Assistant Professor,

City C U Shah Commerce College

CommerceGujarat University, Ahmedabad
Dr. Jignesh Kauangal

\&

Ph.D Guide

Principal

Shree Narayan College of

Gujarat University, Ahmedabad 